\title{
Use patterns, use values and management of Afzelia africana Sm. in Burkina Faso: implications for species domestication and sustainable conservation
}

Larba Hubert Balima ${ }^{1,2^{*}}$ (D) Blandine Marie Ivette Nacoulma ${ }^{2}$, Marius Rodrigue Mensah Ekué3, François N'Guessan Kouamé ${ }^{1}$ and Adjima Thiombiano ${ }^{2}$

\begin{abstract}
Background: The lack of literature on the interactions between indigenous people and the valuable agroforestry trees hinder the promotion of sustainable management of plant resources in West African Sahel. This study aimed at assessing local uses and management of Afzelia africana Sm. in Burkina Faso, as a prerequisite to address issues of domestication and sustainable conservation.

Methods: One thousand forty-four peoples of seven dominant ethnic groups were questioned in 11 villages through 221 semi-structured focus group interviews. The surveys encompassed several rural communities living around six protected areas along the species distribution range. Questions refer mainly to vernacular names of $A$. africana, locals' motivations to conserve the species, the uses, management practices and local ecological knowledge on the species. Citation frequency was calculated for each response item of each questionnaire section to obtain quantitative data. The quantitative data were then submitted to comparison tests and multivariate statistics in R program.

(Continued on next page)
\end{abstract}

\footnotetext{
* Correspondence: Ihubertbalima@gmail.com

${ }^{1}$ West African Science Service Center on Climate Change and Adapted Land

Use (WASCAL) Graduate Research Program on Climate Change and

Biodiversity, Unité de Formation et de Recherche Biosciences, Université Félix

Houphoüet Boigny, BP 165, Abidjan 31, Côte d'Ivoire

${ }^{2}$ Department of Plant Biology and Physiology, Laboratory of Plant Biology

and Ecology, University Ouaga I Pr. Joseph Ki-Zerbo, 03 Box 7021,

Ouagadougou 03, Burkina Faso

Full list of author information is available at the end of the article
} 
(Continued from previous page)

Results: A. africana is a locally well-known tree described as a refuge of invisible spirits. Due to this mystery and its multipurpose uses, A. africana is conserved within the agroforestry systems. The species is widely and mostly used as fodder (87.55\%), drugs (75.93\%), fetish or sanctuary (70.95\%), food (41.49\%), and raw material for carpentry (36. 19\%) and construction (7.05\%). While the uses as fodder, food and construction involved one organ, the leaves and wood respectively, the medicinal use was the most diversified. All tree organs were traditionally used in 10 medical prescriptions to cure about 20 diseases. The species use values differed between ethnic groups with lower values within the Dagara and Fulani. The findings reveal a total absence of specific management practices such as assisted natural regeneration, seeding, or transplantation of A. africana sapling. However, trees were permanently pruned and debarked by local people. Harvesting of barks mostly contributed to the decline of the species populations. Local people acknowledged declining populations of A. africana with lower densities within the agroecosystems. They also perceived between individuals, variations in the traits of barks, leaves, fruits and seeds. Significant differences were found between ethnic groups and gender regarding the species uses. Local knowledge on the species distribution differed between ethnic groups.

Conclusion: This study showed the multipurpose uses of A. africana throughout Burkina Faso. The results provide relevant social and ecological indicators to all stakeholders and constitute a springboard towards the species domestication and the elaboration of efficient sustainable conservation plans.

Keywords: African mahogany, Local knowledge, Sustainability, Sahel, West Africa,

\section{Background}

In the Sahelian countries, most people living in rural areas rely on wild plant products for their daily subsistence [1-4]. The traditional plants use worldwide represents an invaluable reservoir of knowledge and a large potential of yet undiscovered use of natural resources [5]. In fact, a frequent use of wild plants and a transmission of knowledge from generation to generation give indigenous people a profound knowledge of plant resources in the local environment [6]. Local knowledge relates to the useful species, traditional plant uses and forestry management practices $[5,6]$. Such informations are incontestably fundamental for any management strategies aimed at sustainable conservation of plant resources $[3,6]$. Therefore, local knowledge can complement scientific data in the global frame of biodiversity management.

Ethnobotanical studies conducted in West Africa reported the uses of forest products by indigenous people to satisfy their daily needs [1,3-5]. However, a little attention has been paid to the interactions between farmers and agroforestry trees within the agroecosystems. Yet, agroforestry systems provide ecosystem services and reduce human impacts on natural forests [7], and therefore contribute to carbon sequestration [8] and biodiversity conservation [9]. Indeed, agrobiodiversity contributes to improve local people incomes, food security and nutrition [10]. However, the current coupled effects of climate change and land cover change are leading to an increasing habitat loss for many useful plants [5] reducing their goods and services. Therefore, it is important to valorize local valuable plants in order to achieve their domestication and their sustainable conservation in the agroforestry systems. The valorization and domestication of plants require scientific approach based on indigenous knowledge on their use forms and use values and locals' conservation strategies and perceptions of species variation.

Afzelia africana Sm. (called African mahogany or African oak) is an African legume tree species with high socio-economic, industrial, cultural and ecological importance [11]. The species belongs to the FabaceaeCaesalpinioideae family and is distributed in the West African savannahs and forests ranging from the Sudanian Regional Centre of Endemism to the GuineoCongolean Regional Centre of Endemism [11, 12]. A. africana leaves are used in human feeding and constitute forage for livestock [13-15]. Moreover, the wood is overexploited and commercialized for various industrial needs [11] while the barks abound in various medicinal properties [12, 16]. A. africana embodies also spiritual values for some ethnic groups in West Africa [11, 17]. Studies revealed that the natural regeneration of this species is low in Burkina Faso [18, 19]. A. africana is also facing an overexploitation by communities across West African countries [14, 20, 21] resulting in a decline of its natural populations. Therefore, it is considered as a threatened species in many countries [20, 22, 23].

Over the last decade, several studies evaluated local knowledge on the valuable woody plant species of West Africa [3, 24-27]. These studies showed how location [27], ethnicity [3, 26], gender [24] and age [3, 25] influence the uses of plant resources. Despite the threats reported by some authors on the species [14, 20-22], few ethnobotanical data are available on A. africana. The use forms, use values, management practices and local 
perceptions on the dynamics and morphological variations of this species are undocumented. Such data are however prerequisites to address the species valorization and domestication issues.

The study addressed these issues within several rural communities living around six protected areas along the distribution range of $A$. africana in Burkina Faso. These surrounding peoples encompass both autochthons and migrants of seven dominant ethnic groups of different cultural backgrounds. We aimed at assessing the use forms, use values, management practices and local ecological knowledge on the species for its more reasonable use and sustainable conservation. Indeed, understanding how rural communities use and manage plant resources, and analyzing their ecological knowledge on the species, and the drivers behind, are indispensable supports towards the species sustainability.

The following research questions were addressed: (i) What are the use forms of $A$. africana and how are the use values distributed across ethnic groups? (ii) What are local management practices and their impacts on the species survival? (iii) How do local people perceive the spatiotemporal dynamics and the morphological variations of the species? (iv) Which factor does affect local uses and ecological knowledge on the species? Given the wide distribution range of $A$. africana in the country and the difference in peoples' cultural backgrounds, we firstly assumed that local people have a greater knowledge on the species uses and that the species utilitarian value differs between ethnic groups. Secondly, we assumed that as both multipurpose $[13,15,16]$ and threatened species [14, 22] along its distribution range, locals have developed various management strategies to ensure the species long-term use, but the harvesting patterns of organs affect negatively the species survival. We thirdly assumed that local people perceive the regressive dynamic of $A$. africana and morphological variations of its individuals in their environment. We finally assumed that as magic tree [11, 17], local uses and ecological knowledge on A. africana are gender specific.

\section{Methods}

\section{Study area}

The study was carried out at the Sudano-sahelian and the Sudanian climatic zones of Burkina Faso which represent the distribution area of $A$. africana in the country. The sites were Kabougou, Tindangou, Katchelli and Yaro in the Sudano-sahelian zone and Djikologo, Folonzo, Ouangolodougou, Fina, Bala, Tiarako and Soukourani in the Sudanian zone (Fig. 1). These villages were selected around six protected areas (PAs) which shelter natural populations of $A$. africana. In the Sudano-sahelian zone, the protected areas consisted of the W National Park and the Singou Reserve located in Eastern Burkina Faso, and the National Park Kaboré Tambi in CenterSouthern. The Wildlife Reserve of Bontioli (South-Western), the Total Reserve of Comoé Leraba and the Biosphere Reserve of Hippopotamus Pool (Western) were selected in the Sudanian zone. In the Sudano-sahelian zone, the annual rainfall varies between 600 and $900 \mathrm{~mm}$ over 4 to 5 months while the annual temperature ranges from 20 to $30{ }^{\circ} \mathrm{C}$. The vegetation is composed of a mosaic of various savannah types (shrubs, tree and wooded savannahs) and forests. The Sudanian zone has annual rainfall between 900 and $1100 \mathrm{~mm}$ with a rainy season of 5 to 6 months. This area is characterized by low temperature $\left(20-25^{\circ} \mathrm{C}\right)$. The vegetation consists mainly of savannahs, dry forests and gallery forests [28]. The species are typically Sudano-sahelian in the Sudano-sahelian zone and Sudano-Guinean in the Sudanian one. Rural populations of the study sites are mainly farmers and herders.

\section{Sampling design and ethnobotanical surveys}

Whether rural communities are known to have profound knowledge on plant resources [6], people bordering the PAs are the most knowledgeable regarding the threatened plants from which the PAs remain the main refuges. Based on the nationwide distribution range of $A$. africana, six natural populations (three per climatic zone) of the species were selected in the PAs. Around these PAs, the nearest 11 villages (surrounding villages) were sampled. Seven ethnic groups were finally selected in the villages by considering their dominance and people residence status. People origin or residence status hereby refers to autochthon and migrant. The five dominant ethnic groups of the study sites and the two most important ethnic groups of Burkina Faso were sampled. In the villages of the Sudano-sahelian zone, the autochthon groups Gourmantché and Kasséna were selected. The autochthons Dagara, Bobo and Dioula were sampled in the Sudanian zone given the high cultural diversity of this part of the country. In both climatic zones, the selected migrant groups were Mossi and Fulani. The five autochthon groups represented the most dominant ethnic groups of the study sites. The Mossi and Fulani (migrants) constitute the two most dominant ethnic groups of Burkina Faso [3].

A three-way factorial design of two levels of residence status, seven levels of ethnicity and two levels of gender was employed to select focus groups through a random stratified scheme. Semi-structured focus group interviews were adopted because this survey method confronts directly many informants and enables to record only reliable and unbiased data. Overall, 679 men and 365 women were separately interviewed in 135 and 86 focus groups respectively, each group spanning 5-10 peoples. This unbalanced sampling size between men 


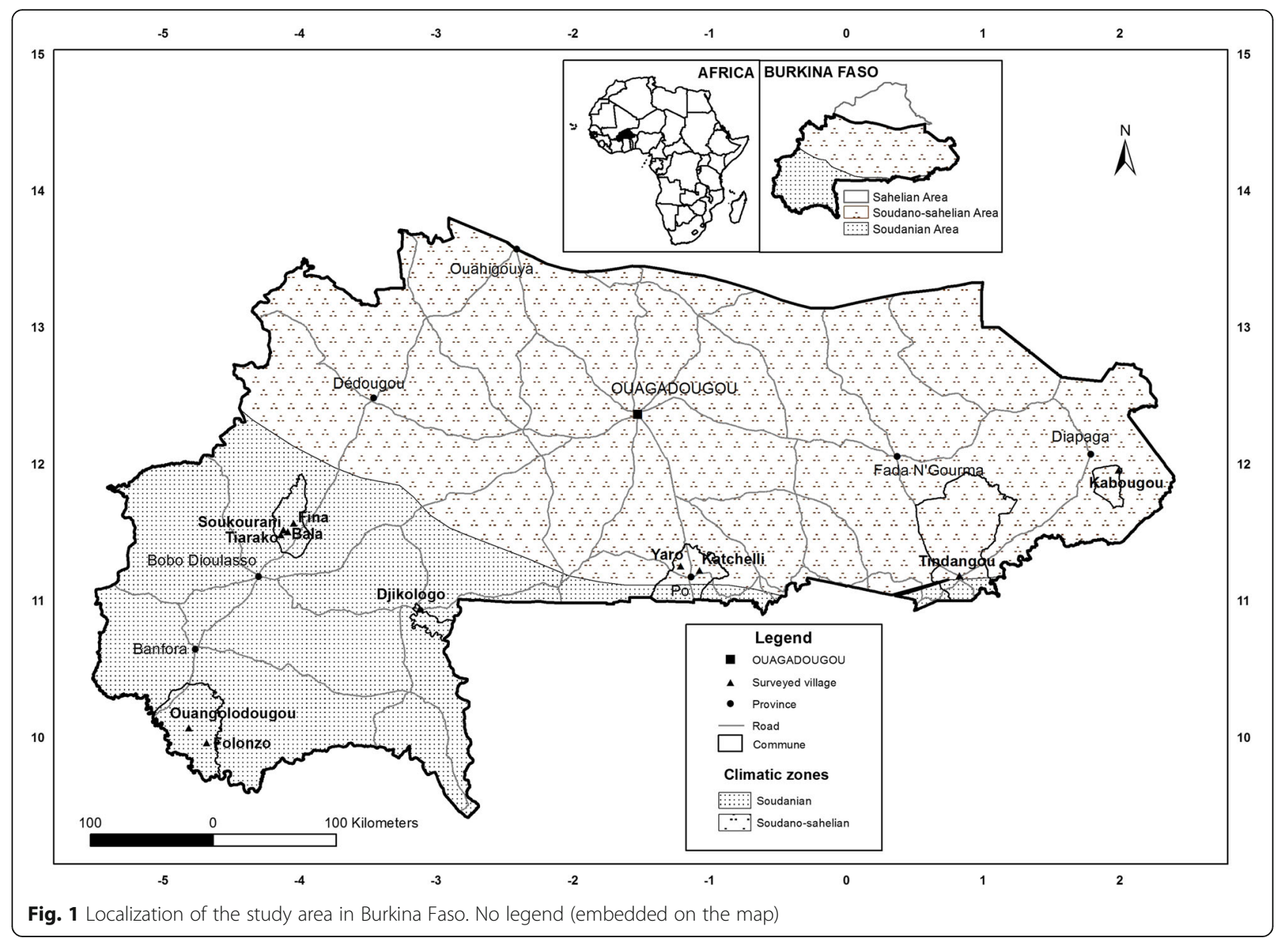

and women was due to the fact men were more available and more willing to be interviewed on the species than women. Given that young peoples usually lack experience [3], surveys were limited to adult persons (at least 30 to 40), so that only experienced informants were interviewed. Informants were questioned about local names of the species and their meanings, the motivations to conserve $A$. africana in the farmlands, the species uses, traditional management practices, and local ecological knowledge on the species.

\section{Data analysis}

At each question section, informants' responses were grouped into answers' groups according to their similarities. These answers were then converted into presence absence matrix of 1 or 0 (signifying whether an informant cites an item or not) [3] comprising informants' ethnic group and gender as line variables, and the responses derived from the aforementioned questions as column variables. The ethnobotanical indicators analyzed through the dataset were the citation frequencies, the fidelity level, the species use values and the index value of organs (Table 1). For each question section, citation frequency was calculated for each response level to convert the presence absence matrix into quantitative data. The frequency of response or citation is defined as the proportion between the number of positive answers (number of citations) for each questionnaire item and the total number of informants.

To determine the species uses, the recorded usages were arranged by use category and the frequency of each use category was computed. The fidelity level representing the degree of consensus between informants was calculated for each use category and used across the ethnic groups to measure the distribution of the species uses among informants.

The fidelity level (FL) was computed as followed [10]:

$$
\mathrm{FL}=\mathrm{Ip} / \mathrm{Iu} \times 100 \%
$$

where Ip represents the number of respondents answering positively to each question item and Iu the total number of positive answers for each question section.

The index value of organs (IVO) was used to determine the most exploited organs. This index was computed using the formula: 
Table 1 Ethnobotanical indicators analyzed through the dataset

\begin{tabular}{|c|c|c|c|c|}
\hline Questions & Items' groups & Variables & Factors & Indices \\
\hline \multirow[t]{4}{*}{ Motivations to conserve } & Agroforestry tree & $\mathrm{FL}, \mathrm{F}$ & $E G, G$ & \\
\hline & Sacred or magic & & & \\
\hline & Multiple uses & & & \\
\hline & Threats & & & \\
\hline \multirow[t]{6}{*}{ Use categories } & Food & $\mathrm{FL}, F$ & $E G, G$ & Use value per EG \\
\hline & Medicinal & & & \\
\hline & Fodder & & & \\
\hline & Culture & & & \\
\hline & Firewood & & & \\
\hline & Construction & & & \\
\hline \multirow[t]{5}{*}{ Organs exploited } & Leaves & $F$ & $E G, G$ & Index value of organ \\
\hline & Barks & & & \\
\hline & Wood & & & \\
\hline & Fruits & & & \\
\hline & Seeds & & & \\
\hline \multirow[t]{7}{*}{ Local practices } & Natural RGN & $\mathrm{FL}, F$ & $E G, G$ & \\
\hline & Assisted RGN & & & \\
\hline & Seeding & & & \\
\hline & Transplantation & & & \\
\hline & Pruning & & & \\
\hline & Debarking & & & \\
\hline & Fire protection & & & \\
\hline \multirow[t]{5}{*}{ Occurrence habitats } & Protected areas & $\mathrm{FL}, F$ & $E G, G$ & \\
\hline & Sacred groves & & & \\
\hline & Fallows & & & \\
\hline & Farmlands & & & \\
\hline & Human settlements & & & \\
\hline \multirow[t]{2}{*}{ Species status } & Abundant & $\mathrm{FL}, F$ & $\mathrm{EG}, \mathrm{G}$ & \\
\hline & Rare & & & \\
\hline \multirow[t]{3}{*}{ Variations criteria } & Tree size & $\mathrm{FL}, F$ & $E G, G$ & \\
\hline & Tree density & & & \\
\hline & Tree morphology & & & \\
\hline Existence of ecotypes & Yes/no & $F$ & $E G, G$ & \\
\hline
\end{tabular}

$F$ citation frequency, $F L$ fidelity level, $E G$ ethnic group, $G$ gender, $R G N$ regeneration

$$
\mathrm{IVO}=\sum N_{\mathrm{u} i} \times 1 / N_{\mathrm{tu}}
$$

where $N_{\mathrm{u} i}$ is the number of uses patterns of each organ quoted by informants $i$ and $N_{\mathrm{tu}}$ the total number of uses of all organs quoted by the informants $N$.

The IVO were compared between organs using the parametric paired $T$ test.

The usefulness of $A$. africana expressed by its use values (UVs) was assessed for each ethnic group using the following formula [29]:

$$
\mathrm{UVs}=\sum \mathrm{UV}_{i s} \times 1 / N_{s}
$$

where $\mathrm{UV}_{\text {is }}$ equals to the use value of the species $s$ for an informant $i$ and $N_{s}$ the total number of persons interviewed for the species $s$.

The UVs were also compared between ethnic groups through the paired $T$ test to determine which ethnic groups used mostly the species.

The management practices developed by locals were analyzed via the fidelity level. 
Local ecological knowledge on the species were also assessed using the fidelity for such questionnaire item.

To identify the drivers of people knowledge on $A$. africana, multivariate statistics and comparison tests were performed. The matrix of frequencies of all responses was first submitted to principal component analysis (PCA) to determine the links between people knowledge and their ethnic-gender memberships. Thus, the seven ethnic groups were divided into 14 subgroups by considering the gender. The 14 subgroups were then codified using the three first letters of the corresponding ethnic group and the first letter of the gender [10]. Finally, the non-parametric Kruskal-Wallis test was performed to seek for significant differences in local knowledge with regard to ethnicity and gender. All the statistical analyses were performed using $\mathrm{R}$ program ( $R$ version 3.2 .2 ).

\section{Results}

Local names of $A$. africana

A. africana is identified through different names according to the ethnic groups (Table 2). Overall, these names referred to the inhabitants of the species known as "evil doing spirits", and the associated mystery or enigma. The names also related to the high fodder value of $A$. africana and the high resistance of its wood.

\section{Local motivations and use categories}

African mahogany is conserved within the traditional agroforestry systems for various reasons. The main reasons include its sacredness to rural communities, its agroforestry potential and its multipurpose uses (Table 3).

All the parts of $A$. africana were used for a wide range of purposes that can be grouped in ten main use categories (Fig. 2). The most important uses were fodder $(87.55 \%)$, medicine $(75.93 \%)$, culture $(70.95 \%)$, and food (41.49\%).

The fidelity levels (Table 3 ) highlighted the fodder use by all ethnic groups $(21.30<\mathrm{FL}<31.71)$, the medicinal use by the Bobo, the Dagara, the Dioula, the Gourmantché and the Kasséna $(20.55<\mathrm{FL}<31.67)$, the cultural use by the Bobo and the Dagara $(21.28<\mathrm{FL}<31$.
67), and the use as food by the Kasséna and Mossi (25. $86<\mathrm{FL}<27.86)$.

\section{Plant parts exploited and use values}

A. africana parts exploited were roots, barks, seeds, fruits husk, leaves, aril and fruits. The index value of organs (IVO) showed that the leaves were the most exploited part, followed by wood and bark (Table 4). However, the seeds, the roots and the aril were less used.

The use values revealed that $A$. africana spans mainly three to four use categories $(2.80 \leq \mathrm{UV} \leq 3.81)$. This index was higher within the Bobo, the Dioula, the Gourmantché, the Kasséna and the Mossi than the Dagara and Fulani (Table 5).

\section{Management practices}

The individuals of $A$. africana were naturally regenerated within the agricultural systems. Practices such as seeding, assisted natural regeneration, or sapling transplantation were absent. However, trees were permanently pruned $(32.94<\mathrm{FL}<76.47)$ and debarked $(23.53<$ $\mathrm{FL}<50$ ) by local people. Debarking and pruning were mainly practiced by traditional healers and herders to harvest medicinal organs and forage respectively. Pruning was also practiced by farmers to reduce the shade effects on crops productivity (Table 3). Additionally, some trees of the species were systematically eliminated from the farmlands.

\section{Local ecological knowledge}

Informants acknowledged that $A$. africana is found in all land use types. More than $50 \%$ of informants from most ethnic groups reported $A$. africana as a threatened species $(51.28<\mathrm{FL}<100)$. The protected areas and the sacred groves were cited as areas with high abundance of the species. Several criteria classified into three main groups were recorded regarding local perceptions of variation of $A$. africana individuals and populations within and between habitats and land use types. The criteria related to tree structure (size and density) and functional treats (bark texture, bark color, shape of

Table $\mathbf{2}$ Local names and their meanings

\begin{tabular}{|c|c|c|}
\hline Ethnic group & Local names & Meanings \\
\hline Bobo & Kibi & Dwarfs' refuges, sacred species \\
\hline Dagara & Kakala, kontontiè, kontontiénou & Dwarfs' refuges, dangerous species \\
\hline Dioula & Linguè & Invisible spirits, sacred species \\
\hline Gourmantché & Bu nakpambu/kpambu, Linakpanli & Sacred, fodder species, sanctuary \\
\hline Kasséna & Kolo & Invisible spirits, dangerous species \\
\hline Mossi & Kakalga, kankalga & Invisible forces, dwarfs, imps' refuge \\
\hline Fulani & Kakalgahi, Panbouhi, Linguèhè & High fodder species, resistant wooc \\
\hline
\end{tabular}


Table 3 Local knowledge on A. africana in Burkina Faso

\begin{tabular}{|c|c|c|c|c|c|c|c|c|c|c|c|c|c|c|c|}
\hline \multirow[t]{3}{*}{ Criteria } & \multirow[t]{3}{*}{ Proposed variant } & \multirow{2}{*}{\multicolumn{2}{|c|}{$\frac{\text { Bobo }}{(n=37)}$}} & \multirow{2}{*}{\multicolumn{2}{|c|}{$\frac{\text { Dagara }}{(n=40)}$}} & \multirow{2}{*}{\multicolumn{2}{|c|}{$\frac{\text { Dioula }}{(n=39)}$}} & \multirow{2}{*}{\multicolumn{2}{|c|}{$\frac{\text { Gourmantché }}{(n=29)}$}} & \multirow{2}{*}{\multicolumn{2}{|c|}{$\frac{\text { Kasséna }}{(n=40)}$}} & \multirow{2}{*}{\multicolumn{2}{|c|}{$\frac{\text { Mossi }}{(n=16)}$}} & \multirow{2}{*}{\multicolumn{2}{|c|}{$\frac{\text { Fulani }}{(n=20)}$}} \\
\hline & & & & & & & & & & & & & & & \\
\hline & & $F$ & $\mathrm{FL}$ & $\bar{F}$ & $\mathrm{FL}$ & $F$ & $\mathrm{FL}$ & $F$ & $\mathrm{FL}$ & $\bar{F}$ & $\mathrm{FL}$ & $F$ & $\mathrm{FL}$ & $F$ & $\mathrm{FL}$ \\
\hline \multirow[t]{5}{*}{ Motivations to conserve } & Agroforestry & 16 & 55.17 & 23 & 63.89 & 28 & 77.78 & 3 & 25 & 20 & 55.56 & 1 & 33.33 & 3 & 50 \\
\hline & Culture & 6 & 20.69 & 7 & 19.44 & 6 & 16.67 & 7 & 58.33 & 14 & 38.89 & 1 & 33.33 & 2 & 33.33 \\
\hline & Multipurpose uses & 5 & 17.24 & 6 & 16.67 & 2 & 5.56 & 1 & 8.33 & 2 & 5.56 & 1 & 33.33 & 1 & 16.67 \\
\hline & Threats & 2 & 6.90 & 0 & 0 & 0 & 0 & 1 & 8.33 & 0 & 0 & 0 & 0 & 0 & 0 \\
\hline & $\Sigma F$ & 29 & - & 36 & - & 36 & - & 12 & - & 36 & - & 3 & - & 6 & - \\
\hline \multirow[t]{11}{*}{ Use categories } & Food & 10 & 7.09 & 0 & 0 & 14 & 9.59 & 19 & 17.59 & 39 & 27.86 & 15 & 25.86 & 3 & 5.36 \\
\hline & Medicine & 37 & 26.24 & 38 & 31.67 & 30 & 20.55 & 28 & 25.93 & 32 & 22.86 & 10 & 17.24 & 8 & 14.29 \\
\hline & Fodder & 36 & 25.53 & 39 & 32.5 & 39 & 26.71 & 23 & 21.30 & 39 & 27.86 & 15 & 25.86 & 20 & 35.71 \\
\hline & Carpentry & 16 & 11.35 & 5 & 4.17 & 27 & 18.49 & 17 & 15.74 & 1 & 0.71 & 11 & 18.97 & 10 & 17.86 \\
\hline & Culture & 30 & 21.28 & 38 & 31.67 & 22 & 15.07 & 18 & 16.67 & 15 & 10.71 & 4 & 6.90 & 2 & 3.57 \\
\hline & Firewood & 3 & 2.13 & 0 & 0 & 0 & 0 & 3 & 2.78 & 9 & 6.43 & 2 & 3.45 & 1 & 1.79 \\
\hline & Construction & 4 & 2.84 & 0 & 0 & 8 & 5.48 & 0 & 0 & 1 & 0.71 & 0 & 0 & 4 & 7.14 \\
\hline & Shade & 3 & 2.13 & 0 & 0 & 5 & 3.42 & 0 & 0 & 4 & 2.86 & 0 & 0 & 1 & 1.79 \\
\hline & Veterinary & 1 & 0.71 & 0 & 0 & 0 & 0 & 0 & 0 & 0 & 0 & 1 & 1.72 & 7 & 12.5 \\
\hline & Fertilization & 1 & 0.71 & 0 & 0 & 1 & 0.68 & 0 & 0 & 0 & 0 & 0 & 0 & 0 & 0 \\
\hline & $\Sigma F$ & 141 & - & 120 & - & 146 & - & 108 & - & 140 & - & 58 & - & 56 & - \\
\hline \multirow[t]{5}{*}{ Species regeneration } & Assisted & 0 & 0 & 0 & 0 & 1 & 2.56 & 1 & 3.45 & 1 & 2.5 & 0 & 0 & 0 & 0 \\
\hline & Natural & 37 & 100 & 40 & 100 & 38 & 97.44 & 28 & 96.55 & 39 & 97.5 & 15 & 100 & 20 & 100 \\
\hline & Sowing & 0 & 0 & 0 & 0 & 0 & 0 & 0 & 0 & 0 & 0 & 0 & 0 & 0 & 0 \\
\hline & Transplantation & 0 & 0 & 0 & 0 & 0 & 0 & 0 & 0 & 0 & 0 & 0 & 0 & 0 & 0 \\
\hline & $\Sigma F$ & 37 & - & 40 & - & 39 & - & 29 & - & 40 & & 15 & - & 20 & - \\
\hline \multirow[t]{4}{*}{ Local practices } & Pruning & 15 & 51.72 & 28 & 48.57 & 33 & 56.90 & 17 & 47.22 & 28 & 32.94 & 8 & 50 & 13 & 76.47 \\
\hline & Debarking & 11 & 37.93 & 19 & 32.76 & 25 & 43.10 & 18 & 50 & 25 & 29.41 & 8 & 50 & 4 & 23.53 \\
\hline & Fire protection & 3 & 10.34 & 11 & 18.97 & 0 & 0 & 1 & 2.78 & 32 & 37.65 & 0 & 0 & 0 & 0 \\
\hline & $\Sigma F$ & 29 & - & 58 & - & 58 & - & 36 & - & 85 & & 16 & - & 17 & - \\
\hline \multirow[t]{3}{*}{ Species status } & Abundant & 12 & 32.43 & 28 & 84.85 & 7 & 17.95 & 4 & 44.44 & 19 & 48.72 & 2 & 33.33 & 0 & 0 \\
\hline & Rare & 25 & 67.57 & 5 & 15.15 & 32 & 82.05 & 5 & 55.56 & 20 & 51.28 & 4 & 66.67 & 9 & 100 \\
\hline & $\Sigma F$ & 37 & - & 33 & - & 39 & - & 9 & - & 39 & - & 6 & - & 9 & - \\
\hline \multirow[t]{6}{*}{ Occurrence habitats } & Farmlands & 13 & 16.25 & 37 & 22.98 & 35 & 23.65 & 12 & 21.43 & 29 & 28.16 & 8 & 22.22 & 6 & 18.18 \\
\hline & Fallows & 12 & 15 & 36 & 22.36 & 35 & 23.65 & 9 & 16.07 & 31 & 30.10 & 7 & 19.44 & 5 & 15.15 \\
\hline & Human settlements & 7 & 8.75 & 18 & 11.18 & 15 & 10.14 & 4 & 7.14 & 0 & 0.00 & 3 & 8.33 & 1 & 3.03 \\
\hline & Protected areas & 32 & 40 & 38 & 23.60 & 35 & 23.65 & 20 & 35.71 & 38 & 36.89 & 13 & 36.11 & 14 & 42.42 \\
\hline & Sacred groves & 16 & 20 & 32 & 19.88 & 28 & 18.92 & 11 & 19.64 & 5 & 4.85 & 5 & 13.89 & 7 & 21.21 \\
\hline & $\Sigma F$ & 80 & - & 161 & - & 148 & - & 56 & - & 103 & - & 36 & - & 33 & - \\
\hline \multirow[t]{4}{*}{ Variations criteria } & Trees' size & 21 & 70 & 12 & 66.66 & 28 & 45.16 & 18 & 75 & 17 & 53.12 & 7 & 63.63 & 11 & 78.57 \\
\hline & Trees' density & 2 & 6.67 & 2 & 11.11 & 8 & 12.90 & 2 & 8.33 & 10 & 31.25 & 0 & & 0 & 0 \\
\hline & Trees' morphology & 7 & 23.33 & 4 & 22.22 & 26 & 41.93 & 4 & 16.67 & 5 & 15.62 & 4 & 36.36 & 3 & 21.43 \\
\hline & $\Sigma F$ & 30 & - & 18 & - & 62 & - & 24 & - & 32 & - & 11 & - & 14 & - \\
\hline
\end{tabular}

$n$ number of interviewees per ethnic group, $F$ frequency, $\Sigma F$ sum of frequency per item, $F L$ fidelity level

leaves, fruits, and seeds). Besides, "harmful" or taboo trees ("trees which shelter invisible spirits") were enigmatically distinguished from "not harmful" trees ("those which house good spirits"). However, informants did not mention any presence of other Afzelia species in their areas. 


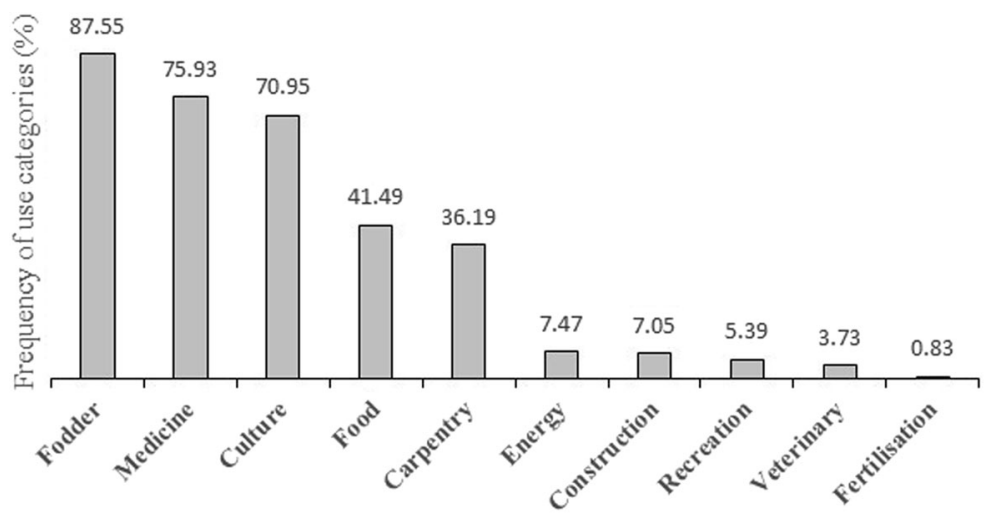

Use categories

Fig. 2 Use categories of A. africana. No legend

\section{Determinants of local knowledge}

The cumulative percentage of variances derived from the principal component analysis (PCA) revealed that the first two dimensions explain 72.47 and 9.09 of the total variation respectively (Fig. 3). Therefore, these principal components (explaining almost $82 \%$ of the total variation) were used to describe the links between people knowledge and their memberships. Figure 3 reveals that all ethnic groups of both sexes are positively correlated with the first axe.

From the correlation matrix (Table 6) and Fig. 3, it appears that women and men from the seven ethnic groups conserved $A$. africana for the same motivations (sacred and threatened species, multipurpose uses).

No significant difference was observed among ethnic groups and gender regarding local motivations to conserve the species (Table 7).

The variables leave, wood and bark positively correlated with the principal component 1 (Table 6) represent the main used products. These products are used to address 20 diseases and to fulfill 10 magico-religious practices. The medicinal uses of the species varied significantly between ethnic groups $(p=0.006)$ and gender $(p=0.004)$ (Table 7). Similarly, significant differences

Table 4 Comparison of index values of organs

\begin{tabular}{lll}
\hline Organs & IVO & T test \\
\hline Barks & 11.67 & $\mathrm{ab}$ \\
Fruits & 7.70 & $\mathrm{~b}$ \\
Fruit husk & 0.48 & $\mathrm{~b}$ \\
Leaves & 46.33 & $\mathrm{a}$ \\
Seeds & 4.69 & $\mathrm{~b}$ \\
Roots & 6.50 & $\mathrm{~b}$ \\
Wood & 22.50 & $\mathrm{ab}$ \\
Aril & 0.12 & $\mathrm{~b}$ \\
\hline
\end{tabular}

$a * b$ : The levels non-connected by the same letters are significantly different were observed between ethnic groups $(p=0.047)$ and gender $(p=0.012)$ regarding the cultural uses.

The species was found in all land use types with significant differences among ethnic groups regarding the occurrence habitats $(p=0.039)$. However, informants perceived the species rarer in their areas and observed variations in tree size, density, and functional treats. Assisted natural regeneration of $A$. africana was absent. However, local people practiced debarking and pruning. The second axe separates the Dagara and Kasséna of both sexes from the five other ethnic groups. Both genders of the Dagara and Kasséna ethnic groups are highly correlated with the principal component 2, with positive correlation values $(r \geq 0.5)$ in contrast to the other ethnic groups. From this second principal component, it appears that male and female Dagara and Kasséna used $A$. africana in carpentry, found its populations abundant in their areas, and protected the species from fire.

\section{Discussion}

Importance of $A$. africana to rural communities

$A$. africana is well known by rural communities who identify it through different names. Nevertheless, some names are phonetically similar between ethnic groups. This involves the denominations Kakala, Kankalga, and

Table 5 Comparison of species use values (UVs)

\begin{tabular}{llc}
\hline Ethnic group & UVs & T test \\
\hline Bobo & 3.81 & $\mathrm{a}$ \\
Dagara & 3.00 & $\mathrm{~b}$ \\
Dioula & 3.74 & $\mathrm{a}$ \\
Gourmantché & 3.72 & $\mathrm{a}$ \\
Kasséna & 3.50 & $\mathrm{a}$ \\
Mossi & 3.62 & $\mathrm{a}$ \\
Fulani & 2.80 & $\mathrm{~b}$ \\
\hline
\end{tabular}

a*b: The levels non-connected by the same letters are significantly different 


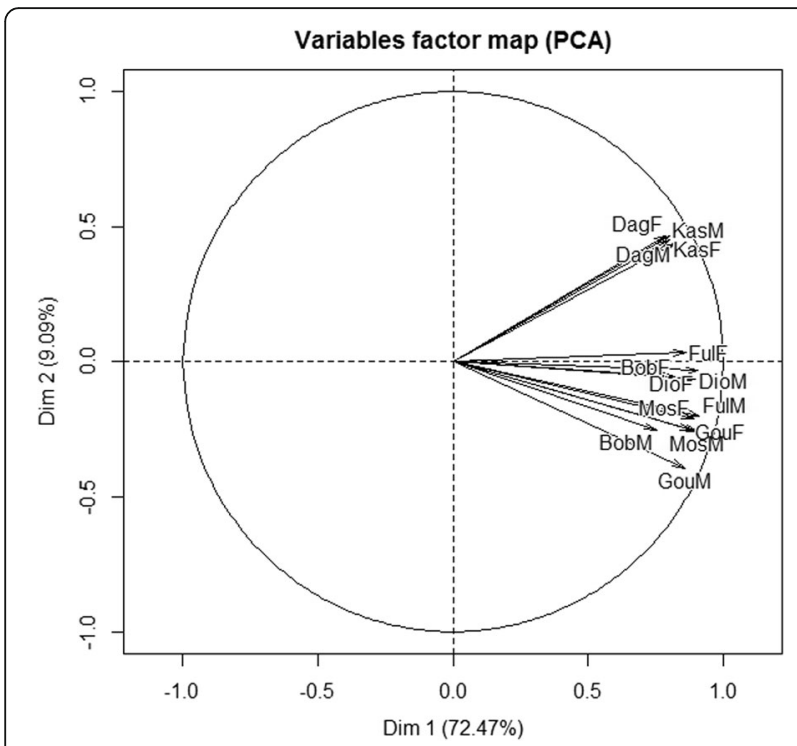

Fig. 3 Projection of ethnic-gender groups into the PCA axes. Dim1: principal component 1; Dim2: principal component 2; BobF: female Bobo; BobM: male Bobo; DagF: female Dagara; DagM: male Dagara; DioF: female Dioula; DioM: male Dioula; FulF: female Fulani; FulM: male Fulani; GouF: female Gourmantché; GouM, male Gourmantché: KasF: female Kasséna; KasM: male Kasséna, MosF: female Mossi, MosM: male Mossi

Kakalgahi respectively from the Dagara, Mossi and Fulani, and Linguè, Linguèhè from the Dioula and Fulani. Overall, these names referred to the inhabitants of the species that is locally perceived as a taboo or magical tree [17]. For instance, the name "Kontontiè" in Dagara means dwarfs or evils whereas "Bunakpambu" in Gourmantché refers to shrines, fetishes, or sanctuaries. Through these names, $A$. africana is considered as a taboo or magico-mystic tree sheltering invisible forces, as reported on Sterculia setigera Delile in Togo [30]. The mystery and the fear linked to the invisible forces and the species multipurpose uses justify its conservation within the agroecosystems.

This study demonstrated that rural Burkinabès have good knowledge on the sociocultural value of the legume tree $A$. africana. Therefore, it contributes to preserving traditional knowledge on wild plant uses, as a basis to guiding conservation actions. The results clearly indicated that $A$. africana is a multipurpose agroforestry species and confirmed several studies across West Africa $[2,11,13,23]$. The species is widely used by rural communities in livestock breeding, food, pharmacopeia, culture, construction and carpentry. Animal fodder and traditional medicine constituted the first two most important uses of this Fabaceae species, corroborating Zizka et al. [5] who found that the medicinal and cultural uses were the most important within the Fabaceae plants in Burkina Faso. The leaves are used to feed cattle during the dry season in the Sahelian countries where forage scarcity severely handicaps animal breeding. The high fodder value of $A$. africana leaves highlighted by informants also corroborates studies conducted in Southwestern and Western Burkina Faso [13, 15]. The leaves are also used as vegetables by some locals [2, 19].

The medicinal uses were the most diversified with more than 20 diseases addressed with $A$. africana organs. This is consistent with other authors $[1-3,5]$ who highlighted the importance of traditional medicine to rural peoples in Burkina Faso. In fact, most peoples living in rural areas strongly rely on many medicinal plants for their healthcare. The barks were reported to be highly medicinal, as confirmed by prior studies $[11,12$, 16]. The decoction and/or the powder of all tree parts (barks, leaves, roots, seeds, and husks) were recognized as being efficiently used to address several infections, as also indicated by Orwa et al. [12].

The magico-mythical properties of $A$. africana as also reported [12, 17] make this species very useful in magico-religious fulfilments such as farmlands, human, or families protecting against invisible forces, wizards, and enemies. Considered as fetish, A. africana trees and organs are used to fulfill people spiritualities such as achieving crop productivity, power, fecundity, and richness. These cultural uses of plant resources have been largely quoted in Burkina Faso [4], in Togo [30], and in Benin [31], revealing the links between mankind culture and plants. The sacred or taboo plants are more used in cultural fulfilments [32]. Considering all the medicomagical usefulness of $A$. africana, it is important to convince local people towards its protection.

The wood was cited as a good source for various craft items and was traditionally used for manufacturing pickaxes, mortars, pestles, spatula, traditional guns, canoe and djembé. These results are in accordance with other studies $[11,12]$ which showed that A. africana wood is termite resistant making it highly commercial and excellent for various industrial purposes. These good mechanical properties of the wood [11] confer high resistance and long life to the derived craft items. However, A. africana wood was forbidden from being used as firewood within some families and ethnic groups. Similar results were reported on other sacred plants such as Tamarindus indica L. and Diospyros mespiliformis Hochst [16, 17]. In fact, local trees protected by traditional bans are not burnt $[1,3,30]$ because of people beliefs on the enigmatic embodiments of such plants. The burning of these taboo plants would expose the offenders to unpredictable fates. The use in energy of $A$. africana wood by a pregnant woman for instance may result in bad spells, blindness, madness, or devil birth. Such local beliefs corroborate Korbéogo [32] who mentioned that the burning of the Gourmantché sacred 
Table 6 Correlation of the variables to the axes

\begin{tabular}{|c|c|c|c|}
\hline Questionnaire item & Variables & PCA 1 & PCA 2 \\
\hline \multirow[t]{4}{*}{ Motivation to conserve } & Agroforestry species & 0.3349 & -0.2913 \\
\hline & Multipurpose species & 0.8952 & -0.0051 \\
\hline & Sacred species & 0.6105 & -0.1489 \\
\hline & Threatened species & 0.9710 & -0.0100 \\
\hline \multirow[t]{8}{*}{ Organs used } & Leaves & 0.8700 & -0.0080 \\
\hline & Barks & 0.7854 & -0.0777 \\
\hline & Fruits & 0.0298 & -0.2844 \\
\hline & Seeds & 0.1180 & -0.0008 \\
\hline & Roots & 0.0000 & -0.3975 \\
\hline & Wood & 0.6543 & -0.0141 \\
\hline & Trunk & 0.4038 & -0.3732 \\
\hline & Husk & 0.9503 & -0.0034 \\
\hline \multirow[t]{22}{*}{ Uses in medicine } & Headache & 0.6889 & -0.0089 \\
\hline & Stomach-ache & 0.05913 & -0.2962 \\
\hline & Articulations pain & 0.5087 & 0.0000 \\
\hline & Teeth pain & 0.4472 & -0.0441 \\
\hline & Bilharzia & 0.9678 & -0.0050 \\
\hline & Hemorrhoids & 0.8704 & -0.0006 \\
\hline & Meningitis & 0.9774 & -0.0045 \\
\hline & Malaria & 0.9290 & -0.0156 \\
\hline & Blindness & 0.9597 & -0.0001 \\
\hline & Ulcer & 0.9531 & -0.0032 \\
\hline & Sprain & 0.9706 & -0.0028 \\
\hline & Sore & 0.6070 & -0.0647 \\
\hline & Swelling & 0.9540 & -0.0001 \\
\hline & Sexual impotence & 0.9638 & -0.0073 \\
\hline & Undiagnosed diseases & 0.9425 & -0.0044 \\
\hline & Gall & 0.7134 & -0.0000 \\
\hline & Paralysis & 0.9437 & -0.0094 \\
\hline & Mental defect & 0.3844 & -0.0003 \\
\hline & Chronic cough & 0.9427 & -0.0055 \\
\hline & Hard childbirth & 0.9485 & -0.0012 \\
\hline & Fever & 0.9432 & -0.0005 \\
\hline & Vertigo & 0.8076 & -0.0107 \\
\hline \multirow[t]{10}{*}{ Uses in culture } & Family protection & 0.3373 & -0.1476 \\
\hline & Farm guarding & 0.3733 & -0.2412 \\
\hline & Fetish installation & 0.3633 & -0.0896 \\
\hline & Anti-bewitching & 0.5173 & -0.0017 \\
\hline & Magic & 0.5249 & -0.0835 \\
\hline & Anti-madness & 0.9632 & -0.0034 \\
\hline & Strength asking & 0.7955 & -0.0509 \\
\hline & Ask for good season & 0.7438 & -0.0358 \\
\hline & Twin rituals & 0.6846 & -0.0642 \\
\hline & Place of sacrifice & 0.3285 & -0.0772 \\
\hline
\end{tabular}

Table 6 Correlation of the variables to the axes (Continued)

\begin{tabular}{|c|c|c|c|}
\hline Questionnaire item & Variables & PCA 1 & PCA 2 \\
\hline & Veneration & 0.8871 & -0.0231 \\
\hline & Children names & 0.9478 & -0.0001 \\
\hline & Ask for richness & 0.8699 & -0.0320 \\
\hline \multirow[t]{4}{*}{ Uses in carpentry } & Furniture & 0.4243 & 0.5093 \\
\hline & Utensils & 0.4521 & 0.5137 \\
\hline & Farming tools & 0.9561 & -0.0013 \\
\hline & Musical instruments & 0.6554 & -0.0980 \\
\hline \multirow[t]{4}{*}{ Local practices } & Assisted regeneration & 0.2394 & -0.0015 \\
\hline & Pruning & 0.8314 & -0.0140 \\
\hline & Debarking & 0.7582 & -0.0051 \\
\hline & Fire protection & 0.0156 & 0.5596 \\
\hline \multirow[t]{5}{*}{ Occurrence habitats } & Farmlands & 0.7358 & -0.1442 \\
\hline & Fallows & 0.6557 & -0.2050 \\
\hline & Habitations & 0.0002 & -0.0347 \\
\hline & Protected areas & 0.9472 & -0.0176 \\
\hline & Sacred groves & 0.6038 & -0.0070 \\
\hline \multirow[t]{2}{*}{ Species status } & Abundant & 0.0774 & 0.6143 \\
\hline & Rare & 0.4504 & -0.0003 \\
\hline \multirow[t]{3}{*}{ Criteria of variations } & Tree size & 0.8112 & -0.0721 \\
\hline & Density & 0.5643 & -0.0297 \\
\hline & Functional treats & 0.5018 & -0.0137 \\
\hline \multirow[t]{2}{*}{ Existence of ecotypes } & Ecotypes & 0.9601 & -0.0002 \\
\hline & No other species & 0.9643 & -0.0022 \\
\hline
\end{tabular}

Values with $r \geq 0.50$ are presented in italics

plants induces within this ethnic group the manifestation of evil spirits and unlucky events. These traditional bans and beliefs on the nature contribute in a certain measure to protect plant species.

Apart from the uses of $A$. africana reported in this study, other properties of this species were reported elsewhere in Africa. A. africana seeds are consumed by people as a soup thickening agent in Nigeria [12]. It has been proven that these seeds possess extractable oil usable in biofuel production [33]. Furthermore, the seeds' oils are nutritionally useful and possess various household uses [34] and industrial applications [12]. The study reported a traditional use of $A$. africana wood in Burkina Faso. However, A. africana wood called "doussié" has great economic and industrial values elsewhere in Africa [11]. In fact, $A$. africana (Sm.), A. bella (Harms), $A$. bipindensis (Harms), and A. pachyloba (Harms) are the four African Afzelia species traded internationally with Cameroon as the main exporting country $[11,35]$. The average price of Afzelia sawn wood is US\$ 780 per $\mathrm{m}^{3}$ and the other main exporters in Africa are Ghana, Côte d'Ivoire, Congo, and Gabon [35]. The promotion of these properties in Burkina Faso may motivate local 
Table 7 Comparison of people knowledge on A. africana

\begin{tabular}{|c|c|c|c|c|}
\hline Local knowledge & Factor & Degree of freedom & Chi-square & $p$ value \\
\hline \multirow[t]{2}{*}{ Motivation } & EG & 6 & 2.847 & 0.827 \\
\hline & G & 1 & 1.044 & 0.307 \\
\hline \multirow[t]{2}{*}{ Organs used } & EG & 6 & 3.036 & 0.804 \\
\hline & G & 1 & 0.031 & 0.860 \\
\hline \multirow[t]{2}{*}{ Food uses } & EG & 6 & 8.247 & 0.220 \\
\hline & G & 1 & 0.027 & 0.870 \\
\hline \multirow[t]{2}{*}{ Medicinal uses } & EG & 6 & 17.904 & $0.006^{*}$ \\
\hline & G & 1 & 8.280 & $0.004^{*}$ \\
\hline \multirow[t]{2}{*}{ Fodder use } & EG & 6 & 6.000 & 0.423 \\
\hline & G & 1 & 0.125 & 0.723 \\
\hline \multirow[t]{2}{*}{ Cultural use } & EG & 6 & 12.723 & $0.048^{*}$ \\
\hline & G & 1 & 6.318 & $0.012^{*}$ \\
\hline \multirow[t]{2}{*}{ Handicraft use } & EG & 6 & 5.644 & 0.464 \\
\hline & G & 1 & 0.892 & 0.345 \\
\hline \multirow[t]{2}{*}{ Local practices } & EG & 6 & 9.026 & 0.172 \\
\hline & G & 1 & 0.558 & 0.455 \\
\hline \multirow[t]{2}{*}{ Occurrence habitat } & EG & 6 & 13.233 & $0.039^{*}$ \\
\hline & G & 1 & 0.000 & 0.977 \\
\hline \multirow[t]{2}{*}{ Species status } & EG & 6 & 5.083 & 0.533 \\
\hline & G & 1 & 0.256 & 0.613 \\
\hline \multirow[t]{2}{*}{ Perception of variation } & EG & 6 & 5.055 & 0.536 \\
\hline & G & 1 & 1.005 & 0.315 \\
\hline \multirow[t]{2}{*}{ Existence of ecotypes } & EG & 6 & 0.000 & 1.000 \\
\hline & G & 1 & 0.048 & 0.826 \\
\hline
\end{tabular}

EG ethnic group, $G$ gender

*Significant differences at $p<0.05$

people to domesticate the species. This might contribute to enhance local incomes that constitutes the main challenge of the sustainable development goals.

\section{Distribution of use values}

The findings showed that the usefulness of $A$. africana differs according to the ethnic groups. In fact, the use values revealed that the Bobo, Dioula, Gourmantché, Kasséna (natives), and Mossi (migrants) ethnic groups had more knowledge and more uses on A. africana compared to the Dagara (natives) and Fulani (migrants) who displayed the lowest use values. Such variations could be explained by differences in people cultural background, as highlighted by other ethnobotanical findings [3, 26, 27]. The species underuse by the Dagara could be ascribed to their exaggerated magical perception that limits the species uses. The main use of $A$. africana as fodder by the Fulani might explain the low use value observed within this ethnic group. This specific fodder use is consistent with the Fulani tradition as herders. The random distribution of the use values among autochthons and migrants suggest that the utilitarian value given to a species by local people does not depend on their residence status. Therefore, both natives and migrants may be knowledgeable or not on plant uses, depending on people cultural backgrounds and plant distribution range.

\section{Local management strategies}

Compared to other agroforestry species such as Parkia biglobosa (Jacq.) R.Br. ex G.Don, Vitellaria paradoxa C. F.Gaertn., and Tamarindus indica L. which benefit from particular management practices such as assisted natural regeneration, seeding or often sapling transplantation within the farmlands, A. africana seems to be neglected. This might be due to the magic or taboo status of the species. In fact, the myth or taboo associated with $A$. africana constitutes big challenges towards its domestication and sustainable conservation. Although local perception on the sacred or taboo plants are indispensable supports for their conservation [36], the prejudices linked to their inhabitants prevent some farmers to 
maintain them in their farmlands or to assist their regeneration. The ignorance of the economic value of $A$. africana in the local areas might also explain this lack of local management strategies. The trees of $A$. africana were severely pruned and debarked. Informants assumed that foliage harvesting rejuvenates the trees and renews the foliage. These perceptions are consistent with other findings that showed that pruning of Khaya senegalensis (Ders.) A.Juss. improves the quality and quantity of leaves produced [37]. However, the harvesting of barks was perceived by locals as being more prejudicial to the species survival. Indeed, debarking exposes the stem to desiccation, fires, drought and various attacks [38]. It is recognized that harvesting of bark has more negative impacts on the habitat and populations of plant species than leaves and fruits harvesting [27]. Severe pruning weakens the tree [37] whereas severe debarking induces tree mortality in the long term. The combined bark and foliage harvesting decreases the production of fruits and seeds of $A$. africana [38].

\section{Ecological knowledge on $A$. africana}

Due to the absence of regeneration practices and the unsustainable exploitation of $A$. africana, its populations were acknowledged declining in the rural areas across all study sites. This result concurs with other findings in Burkina Faso and Benin where the species is acknowledged threatened $[14,22]$ and endangered $[20,21]$ respectively. The severe pruning and debarking might explain the lower density of the species within the agricultural systems. These variations in tree structure across land use types as reported by locals corroborate findings that indicated the negative effect of land use on the dynamics of A. africana in West Africa [14, 20, 21]. The protected areas that represent the latest refuges for many threatened animals and plants [39] were quoted as principal refuges for $A$. africana.

In contrast to local perceptions on the existence of morphotypes within $A$. africana species, no existence of other Afzelia species was mentioned. These observations are congruent with scientific data supporting that among the seven African Afzelia species, only A. africana is found in Burkina Faso [11]. Nevertheless, the morphological traits reported on the species raise a need for further molecular studies and thorough botanical researches able to testify the occurrence of this unique African Afzelia species in Burkina Faso.

\section{Driving factors of local knowledge}

The motivations to conserve $A$. africana, the species uses, the parts exploited, and the occurrence habitats showed a homogeneous distribution among all ethnic groups of both sexes. However, in contrast to the other ethnic groups, the Dagara and Kasséna of both sexes perceived A. africana abundant in their areas. Such results imply similar global trends in local knowledge of plants across communities on the one hand, and specific cultural habits on the other hand. Indeed, people of different cultural backgrounds might share global similar customs with some variations across communities due to their specific culture. Significant differences were observed between ethnic groups regarding the species medicinal and cultural uses. These variations corroborate other ethnobotanical findings in West Africa that showed the influence of ethnicity on plant uses [3, 10, $25,27]$. This might explain the high diversity of the medicinal and cultural uses of $A$. africana. The medicinal and cultural uses varied also according to gender, as corroborated by studies on other plants [10, 27]. However, these differences observed between men and women disagree with studies which demonstrated that gender is not a determinant of plant uses in Burkina Faso [2, 3, 25]. These disagreements might be due to the magical embodiments of $A$. africana making men more knowledgeable on the species uses than women. Significant differences were also observed between ethnic groups regarding the species habitats. The variability in local ecological and environmental conditions controlling the species distribution and availability [3] could explain such differences between ethnic groups regarding local perceptions on the occurrence habitats and species abundance.

\section{Implications for sustainability}

The present study provides insight into the use patterns and management of African mahogany, and their impacts on the species spatial distribution, as a basis to set up an efficient sustainable conservation plan. The findings provide relevant social and ecological indicators likely to guide local people and decisions' makers towards the species sustainability. The multipurpose uses of $A$. africana reported as the main reason for its in-situ conservation indicate that promoting its domestication will be welcomed by local people, especially the Bobo, Dioula, Gourmantché, Kasséna, and Mossi ethnic groups who gave high utilitarian value to the species. Similarly, considering the recent forage shortage in the Sahel region and the contribution of animal breeding to rural incomes, the high fodder and veterinary value of $A$. africana leaves reported in this study is a key indicator to promote the species domestication. The diverse medicinal properties of $A$. africana offer opportunities for pharmacological researches.

Given its wide distribution range [11, 12] and its wide adaptation to climatological conditions [35], A. africana can be promoted in regional programs of restoration that is a major issue in West Africa under increasing land degradation. With the high economic value of $A$. 
africana wood in Africa [11, 35], promoting its use in national programs of domestication and restoration could increase doussié production and generate important economic incomes. Such programs could also contribute to climate change mitigating via carbon sequestration. Although the seeds' oils of A. africana were reported to be potentially useful for bioenergy production [33], the seeds were neglected and rarely used by rural communities. Therefore, their vulgarization might boost its seedling plantation and capture the attention of global bioenergy market towards the species sustainable conservation.

People perceptions that $A$. africana houses evil-doing spirits might constitute big challenge to meet its domestication. These negative perceptions imply sensitizations that may convince local people to assist the species natural regeneration or to maintain its individuals within the farmlands. The education of local people towards sustainable practices such as soft harvesting patterns could boost a rational use of the species and its sustainable conservation. In this perspective, avoiding debarking or reducing its intensity and frequency is strongly recommended.

The perceptions of rural communities on the habitats and the dynamics of $A$. africana reveal the double function of hotspots and refuges, attributable to the protected areas [39]. Indeed, the protected zones greatly contribute to protecting the threatened species from extinction. These ecosystems remain the latest refuges for many threatened species. More investigations are highly required to explain local perceptions on the diversity of tree functional traits and their variations across individuals and habitats.

Gender and ethnicity aspects should be considered in domestication and sustainable management projects of high-valued tree species such as A. africana.

\section{Conclusion}

This study confirmed that A. africana is a threatened and multipurpose agroforestry tree extensively exploited throughout Burkina Faso. The use values of the species varied according to people cultural backgrounds with the Dagara and Fulani having the least level of knowledge. Despite its multipurpose uses, $A$. africana is neglected within the farmlands with a quasi-total absence of management practices. The harvesting of barks as practiced by traditional healers impacted negatively on the species survival. Local people perceived declined populations of $A$. africana especially in the farmlands. The study also showed that these communities perceived variations in the targeted species populations' structure and trees morphological traits. The uses of $A$. africana were influenced by gender and ethnicity as well. However, only ethnicity affected people knowledge on the species habitats. The study revealed strong concordance between indigenous knowledge and scientific findings.
While the results provide relevant indicators likely to guide conservation decisions, local magical beliefs might constitute severe challenge to domesticate African oak in Burkina Faso.

\section{Abbreviations}

FL: Fidelity level; IFS: International Foundation for Science; IUCN: International Union for Conservation of Nature; IVO: Index value of organs; PAs: Protected areas; PCA: Principal component analysis; UVs: Use value of the species; WASCAL: West African Science Service Center on Climate Change and Adapted Land Use

\section{Acknowledgements}

This research was funded by the International Foundation for Science (IFS) which is gratefully acknowledged. The authors express also their sincere gratitude to the German Federal Ministry of Education and Research, for providing financial and excellent academic supports through the Graduate Research Program Climate Change and Biodiversity of the West African Science Service Center on Climate Change and Adapted Land Use program (WASCAL). Special thanks to local people for having shared their knowledge. Finally, we thank anonymous reviewers who significantly contributed to improve the paper through their comments.

\section{Funding}

This research was financially supported by the International Foundation for Science (IFS) through a research grant provided to Dr. Blandine M.I. Nacoulma (Ref. IFS D 5487-1). The funding helped in the data collection.

\section{Availability of data and materials}

The datasets used and analyzed during the current study are available from the corresponding author on reasonable request.

\section{Authors' contributions}

LHB carried out the field work, performed the statistical analysis, and drafted the manuscript. BMIN designed the research project, gave the practical advices, and read and improved the drafted manuscript. MRME contributed in statistical analysis. AT and FNK supervised the work and improved the manuscript. All the authors read, revised and approved the final manuscript.

Ethics approval and consent to participate

Not applicable

\section{Consent for publication}

Not applicable

\section{Competing interests}

The authors declare that they have no competing interests.

\section{Publisher's Note}

Springer Nature remains neutral with regard to jurisdictional claims in published maps and institutional affiliations.

\section{Author details}

${ }^{1}$ West African Science Service Center on Climate Change and Adapted Land Use (WASCAL) Graduate Research Program on Climate Change and Biodiversity, Unité de Formation et de Recherche Biosciences, Université Félix Houphoüet Boigny, BP 165, Abidjan 31, Côte d'Ivoire. ${ }^{2}$ Department of Plant Biology and Physiology, Laboratory of Plant Biology and Ecology, University Ouaga I Pr. Joseph Ki-Zerbo, 03 Box 7021, Ouagadougou 03, Burkina Faso. ${ }^{3}$ Bioversity International, Forest Genetic Resources and Restoration Team, Box 2008 (Messa), Yaoundé, Cameroon.

Received: 15 September 2017 Accepted: 12 March 2018

Published online: 27 March 2018

\section{References}

1. Lykke AM, Kristensen MK, Ganaba S. Valuation of local use and dynamics of 56 woody species in the Sahel. Biodivers Conserv. 2004;13:1961-90. 
2. Bélem B, Nacoulma BMl, Gbangou R, Kambou S, Hansen HH, Gausset Q, et al. Use of non-wood forest products by local people bordering the "Parc National Kaboré Tambi", Burkina Faso. J Transdiscipl Environ Stud. 2007;6:1-21.

3. Sop TK, Oldeland JS, Bognounou F, Schmiedel U, Thiombiano A. Ethnobotanical knowledge and valuation of woody plants species: a comparative analysis of three ethnic groups from the sub-Sahel of Burkina Faso. Environ Dev Sustain. 2012;8:3.

4. Ouédraogo I, Nacoulma BMI, Hahn K, Thiombiano A. Assessing ecosystem services based on indigenous knowledge in south-eastern Burkina Faso (West Africa). Int J Biodivers Sci Ecosystem Serv Manag. 2014; https://doi. org/10.1080/21513732.2014.950980.

5. Zizka A, Thiombiano A, Dressler S, Nacoulma BMl, Ouédraogo A, Ouédraogo I, et al. Traditional plant use in Burkina Faso (West Africa): a national-scale analysis with focus on traditional medicine. J Ethnobiol Ethnomed. 2015;11:9

6. Lykke AM. Local perceptions of vegetation change and priorities for conservation of woody-savanna vegetation in Senegal. J Environ Manag. 2000;59:107-20.

7. Bayala J, Sanou J, Teklehaimanot Z, Kalinganire A, Ouédraogo SJ. Parklands for buffering climate risk and sustaining agricultural production in the Sahel of West Africa. Curr Opin Environ Sustain. 2014; 6:28-34.

8. Mbow C, Smith P, Skole D, Duguma L, Bustamante M. Achieving mitigation and adaptation to climate change through sustainable agroforestry practices in Africa. Curr Opin Environ Sustain. 2013;6:8-14.

9. Jose S. Agroforestry for conserving and enhancing biodiversity. Agrofor Syst. 2012; https://doi.org/10.1007/s10457-012-9517-5.

10. Ekué MRM, Sinsin B, Eyog-Matig O, Finkeldey R. Uses, traditional management, perceptions of variation and preferences in ackee (Blighia sapida K. D. Koenig) fruits traits in Bénin: implications for domestication and conservation. J Ethnobiol Ethnomed. 2010;6:12.

11. Donkpegan ASL, Hardy OJ, Lejeune P, Oumorou M, Daïnou K, Doucet JL. Un complexe d'espèces d'Afzelia des forêts africaines d'intérêt économique et écologique (synthèse bibliographique). Biotechnol Agron Soc Environ. 2014;18:233-46.

12. Orwa C, Mutua A, Kindt R, Jamnadass R, Anthony R. Agroforestree database 4.0. 2009. http://www.worldagroforestry.org/sites/treedbs/treedatabases.asp. Accessed 22 Feb 2017

13. Ouédraogo-Koné S, Kaboré-Zoungrana CY, Ledin I. Behaviour of goats, sheep and cattle on natural pasture in the sub-humid zone of West Africa. Livest Sci. 2006;105:244-52.

14. Nacoulma BMI, Traoré S, Hahn K, Thiombiano A. Impact of land use types on population structure and extent of bark and foliage harvest of Afzelia africana and Pterocarpus erinaceus in Eastern Burkina Faso. Int I Biodiversity Conserv. 2011;3:62-72.

15. Traoré L, Ouédraogo I, Ouédraogo A, Thiombiano A. Perceptions, usages et vulnérabilité des ressources végétales ligneuses dans le Sud-Ouest du Burkina Faso. Int J Biol Chem Sci. 2011;5:258-78.

16. Taïta P. Use of woody plants by locals in Mare aux Hippopotames Biosphere Reserve in western Burkina Faso. Biodivers Conserv. 2003:12:1205-17.

17. Millogo-Rasolodimby J. Les plantes sacrées chez les Bobos. SFB 268. 1993;5: 93-100.

18. Bationo BA, Ouédraogo SJ, Boussim IJ. Afzelia africana Sm. (Caesalpiniaceae): étude de la prédation des graines dans une savane boisée du Burkina Faso. Bois et Forêts des Tropiques. 2000;264:55-6.

19. Bationo BA, Ouédraogo SJ, Guinko S. Longévité des graines et contraintes à la survie des plantules d'Afzelia africana Sm. dans une savane boisée du Burkina Faso. Ann For Sci. 2001;58:69-75.

20. Sinsin B, Eyog-Matig O, Assogbadjo AE, Gaoué OG, Sinadouwirou T. Dendrometric characteristics as indicators of human pressure on Afzelia africana Sm. dynamic changes in trees found in different climatic zones of Benin. Biodivers Conserv. 2004;13:1555-70.

21. Bonou W, Glèlè Kakaï $R$, Assogbadjo AE, Fonton HN, Sinsin B. Characterisation of Afzelia africana Sm. habitat in the Lama forest reserve of Benin. For Ecol Manag. 2009;258:1084-92.

22. Ouédraogo A, Thiombiano A, Hahn-Hadjali K, Guinko S. Diagnostic de l'état de dégradation des peuplements de quatre espèces ligneuses en zone soudanienne du Burkina Faso. Sécheresse. 2006;17:485-91.

23. Assogbadjo AE, Glèlè Kakai R, Sinsin B. Afzelia africana Caesalpiniaceae: current state of plant diversity. In: Sinsin B, Kampmann D, editors. Biodiversity atlas of West Africa Vol I Benin: Cotonou \& Frankfurt: BIOTA; 2010. p. 288-91.
24. Assogbadjo AE, Glèlè-Kakaï R, Chadare FJ, Thomson L, Kyndt T, Sinsin B, Van Damme P. Folk classification, perception, and preferences of baobab products in West Africa: consequences for species conservation and improvement. Econ Bot. 2008;62:74-84.

25. De Caluwé E, De Smedt S, Assogbadjo AE, Samson R, Sinsin B, Van Damme P. Ethnic differences in use value and use patterns of baobab (Adansonia digitata L.) in northern Benin. Afr J Ecol. 2009;47:433-40.

26. Fandohan B, Assogbadjo AE, Glèlè Kakaï R, Kyndt $T$, De Caluwé E, Codjia JTC, Sinsin B. Women's traditional knowledge, use value, and the contribution of tamarind (Tamarindus indica $\mathrm{L}$.) to rural households' cash income in Benin. Econ Bot. 2010;XX:X.

27. Koura K, Ganglo JC, Assogbadjo AE, Agbangla C. Ethnic differences in use values and use patterns of Parkia biglobosa in Northern Benin. J Ethnobiol Ethnomed. 2011;7:42.

28. Fontès J, Guinko $\mathrm{S}$. Carte de végétation et de l'occupation du sol du Burkina Faso: notice explicative. Toulouse: Ministère de la Coopération Française, Université Paul Sabatier; 1995.

29. Philips O, Gentry AH, Reynel C, Wilkin P, Galvez-Duran CB. Quantitative ethnobotany and Amazonian conservation. Conserv Biol. 1994:8:225-48.

30. Atakpama W, Batawila K, Gnamkoulamba A, Akpagana K. Quantitative approach of Sterculia setigera Delile (Malvaceae), ethnobotanical uses among rural communities in Togo (West Africa). Ethnobot Res Appl. 2015;14:63-80.

31. Codjia JTC, Assogbadjo AE, Ekué MRM. Diversité et valorisation au niveau local des ressources forestières alimentaires du Bénin. Cahiers Agric. 2003;12:321-31.

32. Korbéogo G. Socio-cultural strategies of biodiversity conservation: conservation strategies. In: Thiombiano A, Kampmann D, editors. Biodiversity atlas of West Africa Vol II Burkina Faso: Ouagadougou \& Frankfurt: BIOTA; 2010. p. 430-3.

33. Igwenyi IO, Offor CE, Aja PM, Aloh GS, Orji OU, Afiukwa CA. Potentials of Afzelia africana vegetable oil in biodiesel production. Asian J Biochem. 2011;6:450-7.

34. Ejikeme PM, Obasi LN, Egbuonu ACC. Physico-chemical and toxicological studies on Afzelia africana seed and oil. Afr J Biotechnol. 2010;9:1959-63.

35. Gérard J, Louppe D. Afzelia africana Sm. ex Pers. In: Lemmens RHMJ, Louppe D, Oteng-Amoako AA, editors. Prota, Timbers/Bois d'œuure 2, vol. 7. Wageningen; 2011. p. 2. http://uses.plantnet-project.org/fr/Afzelia_africana_ (PROTA).

36. Savadogo S, Thiombiano A. Sacred groves and community forests: important ecological zones. In: Thiombiano A, Kampmann D, editors. Biodiversity atlas of West Africa Vol II Burkina Faso: Ouagadougou \& Frankfurt: BIOTA; 2010. p. 378-85.

37. Gaoue OG, Ticktin T. Fulani knowledge of the ecological impacts of Khaya senegalensis (Meliaceae) foliage harvest in Benin and its implications for sustainable harvest. Econ Bot. 2009;63:256-70.

38. Nacoulma BMI, Lykke AM, Traoré $S$, Sinsin B, Thiombiano A. Impact of bark and foliage harvesting on fruit production of the multipurpose tree Afzelia africana in Burkina Faso (West Africa). Agrofor Syst. 2016;90:3.

39. Sinsin B. Conflicts and perspectives of biodiversity conservation in West Africa: protected areas conservation issues in West Africa. In: Thiombiano A, Kampmann D, editors. Biodiversity atlas of West Africa Vol II Burkina Faso: Ouagadougou \& Frankfurt: BIOTA; 2010. p. 498-511.

\section{Submit your next manuscript to BioMed Central and we will help you at every step:}

- We accept pre-submission inquiries

- Our selector tool helps you to find the most relevant journal

- We provide round the clock customer support

- Convenient online submission

- Thorough peer review

- Inclusion in PubMed and all major indexing services

- Maximum visibility for your research

Submit your manuscript at www.biomedcentral.com/submit 